\title{
PENYULUHAN PEMBERIAN AMPAS TAHU DAN GAMAL DALAM RANSUM UNTUK MENINGKATKAN BOBOT BADAN DOMBA DI DESA CIAKAR KECAMATAN CIJULANG KABUPATEN PANGANDARAN
}

\section{Counselling on The Use of Tofu and Gamal Dregs in Ransom to Increase The Weight of Sheep in Ciakar Village Cijulang District Pangandaran Regency}

\author{
Cikal Beni Nata*, Wahyuningsih, Arifin Tasrif \\ Program Studi Penyuluhan Peternakan dan Kesejahteraan Hewan \\ Jurusan Peternakan Politeknik Pembangunan Pertanian Bogor \\ *Email: beninata21@gmail.com
}

\begin{abstract}
The use of tofu and Gamal dregs in sheep rations for breeders in Ciakar village is not widely known. Therefore, the objective of this study is to see the extent of knowledge and skills in adopting simple technology regarding the use of tofu and Gamal dregs in sheep feed rations and increasing daily body weight (PPBH) of sheep. The study was carried out from April 5 to June 28, 2021. The treatment was given various doses of tofu and Gamal dregs to the daily weight gain of sheep and a questionnaire to see the level of knowledge and skills of sheep breeders using the additional feed. The results showed that the use of tofu and Gamal dregs was able to increase the PBBH by 171.5 $\mathrm{g} / \mathrm{head} /$ day compared to the control (without giving tofu and Gamal dregs). In addition, the level of knowledge and skills of farmers increased by $52.88 \%$ and skills by $51.29 \%$ with the criteria of success for the adoption of simple technology using additional feed tofu dregs and Gamal in sheep feed rations.
\end{abstract}

Keywords: extension, body weight, income, gamal, tofu dregs

\begin{abstract}
ABSTRAK
Pemanfaatan ampas tahu dan gamal dalam ransum ternak Domba pada peternak di desa Ciakar belum banyak diketahui. Oleh sebab itu Penelitian ini bertujuan untuk melihat sejauh mana tingkat pengetahuan dan keterampilan dalam mengadopsi teknologi sederhana tentang pemanfaatan ampas tahu dan gamal dalam ransum pakan ternak domba dan peningkatan bobot badan harian (PPBH) domba. Penelitian dilaksanakan mulai 5 April s/d 28 Juni 2021. Perlakuan berupa pemberian berbagai dosis ampas tahu dan gamal terhadap pertambahan bobot harian domba dan kuisioner untuk melihat tingkat pengetahun dan keterampilan peternak domba memanfaatkan pakan tambahan tersebut. Hasil penelitian memperlihatkan bahwa pemberian ampas tahu dan gamal mampu meningkatkan PBBH sebesar 171,5 g/ekor/hari dibanding control (tanpa pemberian ampas tahu dan gamal). Demikian pula tingkat pengetahuan dan keterampilan peternak terjadi peningkatan sebesar $52,88 \%$ dan keterampilan sebesar $51,29 \%$ dengan kriteria berhasil terhadap adopsi teknologi sederhana pemanfaatan pakan tambahan ampas tahu dan gamal dalam ransum pakan domba
\end{abstract}

Kata Kunci: ampas tahu, bobot badan, pendapatan, penyuluhan 


\section{PENDAHULUAN}

Populasi domba di Kabupaten Pangandaran dengan jantan mencapai 12.787 ekor dan betina 23.747 (BPS 2019). Kecamatan Cijulang merupakan salah satu wilayah di Kabupaten Pangandaran yang memiliki potensi untuk mengembangkan ternak domba dengan jumlah populasi 2.059 ekor dan luas wilayah $9.316 \mathrm{Ha}$. Sumber daya alam yang ada seperti hijauan dan limbah sisa hasil pertanian selalu tersedia dengan didukung sumber daya manusianya yang sebagain besar bekerja sebagai petani dan buruh tani. Dari 27.256 jiwa total penduduk di Kecamatan Cijulang, sebanyak 17.808 jiwa merupakan penduduk dengan usia produktif dan 15.396 jiwa bermata pencaharian dibidang pertanian dan peternakan. Berdasarkan RKTP yang diperoleh dari BPP masalah yang terdapat di Kecamatan Cijulang yakni masih kurangnya penggunaan konsentrat salah satunya penggunaan ampas tahu.

Ampas tahu merupakan salah satu bahan yang bisa dipakai sebagai bahan penyusun ransum. Sampai saat ini ampas tahu mudah didapat dengan harga terjangkau dan juga bisa secara cumacuma. Ditinjau dari komposisi nutrisi ampas tahu bisa digunakan sebagai sumber protein dan sebagai pakan tambahan. Ampas tahu lebih tinggi kualitasnya dibandingkan dengan kacang kedelai. Prabowo et al. (1983) menyatakan bahwa protein ampas tahu mempunyai nilai biologis lebih tinggi daripada protein biji kedelai dalam keadaan mentah. Hal ini karenabahan ini berasal dari kedelai yang telah dimasak.

Ampas tahu juga mengandung unsur-unsur mineral mikro maupun makro yaitu untuk mikro; Fe 200-500 ppm, Mn 30100 ppm, Cu 5-15 ppm, Co kurang dari 1 ppm, Zn lebih dari 50 ppm. Dalam keadaan segar berkadar air sekitar 84,5\% dari bobotnya. Kadar air yang tinggi dapat menyebabkan umur simpannya pendek. Ampas tahu basah tidak tahan disimpan dan akan cepat menjadi asam dan busuk selama 2-3 hari, sehingga ternak tidak menyukai lagi. Ampas tahu kering mengandung air sekitar 10,0 - 15,5\% sehingga umur simpannya lebih lama dibandingkan dengan ampas tahu segar (Widjatmoko, 1996). Dalam upaya meningkatkan peternakan yang maju, diperlukan inovasi- inovasi teknologi yang dapat mendukung dalam meningkatkan produksi serta produktivitas ternak domba tersebut. Pemanfaatan ampas tahu sebagai pakan tambahan merupakan salah satu teknologi yang dapat diterapkan peternak dalam meningkatkan produkstivitas ternak melalui peningkatan berat badan ternak serta dengan menggunakan ampas tahu sebagai pakan tambahan ternak merupakan upaya dalam pemanfaatan limbah pertanian.

Berdasarkan uraian di atas, maka perlu dilakukan penelitian tentang penyuluhan pemberian ampas tahu dan gamal Sebagai ralam ransum untuk meningkatkan bobot badan domba, sehingga dapat membantu peternak dalam upaya meningkatkan pendapatan ekonomi di sub sektor peternakan. Tujuan yang hendak dicapai dalam pelaksanaan penelitian ini adalah 1) meningkatkan pengetahuan dan keterampilan peternak dalam pemanfaatan ampas tahu dan gamal, 2) meningkatkan bobot badan domba dengan melakukan pemberian ampas tahu dan gamal, 3) mencapai target yang di dapat dari peternak tersebut agar memenuhi kualitas yang baik.

\section{METODE PENELITIAN}

\section{Waktu dan Tempat}

Penelitian ini dilaksanakan pada 05 April sampai 28 Juni 2021, bertempat di Kelompok Tani Muda Taruna II Desa Ciakar Kecamatan Cijulang Kabupaten Pangandaran Provinsi Jawa Barat. 


\section{Materi dan Metode}

Materi yang disampaikan pada kegiatan penyuluhan di Kelompok Tani Muda Taruna II Desa Ciakar yaitu penyuluhan pemberian ampas tahu dan gamal dalam ransum untuk meningkatkan bobot badan domba. mediayang digunakan dalam pelaksanaan penyuluhan adalah powerpoint, penayangan video dan leaflet, LPM (Lembar Persiapan Menyuluh) dan Sinopsis. Metode yang digunakan dalam pelaksanaan penyuluhan adalah dengan menggunakan pendekatan kelompok. Sedangkan teknik penyuluhannya dengan menggunakan teknik ceramah, anjangsana, diskusi dan kaji terap.

\section{Populasi dan Sampel}

Populasi dalam penelitian ini yakni anggotaKelompok Tani Muda Taruna II sebanyak 30 orang di Desa Ciakar Kecamatan Cijulang. Responden diambil secara sengaja (purposive sampling) berdasarkan kriteria yaitu anggota kelompok tani yang memiliki ternak domba sebanyak 2-3 ekor. Sehingga terdapat sampel berjumlah 30 orang. Penelitian dilakukan terhadap domba jantan berjumlah 12 ekor dengan berat awal beragam dari 20 - $29 \mathrm{~kg}$. Domba yang digunakan untuk kegiatan kajiterap adalah milik anggota Kelompok tani Muda Taruna II di Desa Ciakar Kecamatan Cijulang. Sebelum dilakukan kaji terap domba diberikan obat cacing dan vitamin $B$ kompleks dengan dosis $3 \mathrm{ml} / \mathrm{ekor}$.

\section{Evaluasi Penyuluhan}

Penyuluhan ini menggunakan evaluasi awal (pre test) dan evaluasi akhir (post test) penyuluhan yang sudah dilakukan, dievaluasi sesuai dengan tujuan penyuluhan yang telah ditetapkan sehingga dapat diketahui tingkat keberhasilan penyuluhan yang sudah dilakuakn dan dapat diintepretasika. Data disajikan secara transparan dan menggunakan analisis deskriptif.

\section{Analisis Usaha}

Digunakan untuk meninjau kelayakan yang diperoleh dalam usaha yang dijalankan atau dikembangkan. Ada beberapa indikator yang bisa digunakan untuk mengukur kelayakan sebuah usaha, diantaranya Revenue Cost Ratio ( $\mathrm{R} / \mathrm{C}$ ratio), Benefit Cost ratio (B/C ratio) dan Break Event Point (BEP).

\section{Analisis Data}

Data pengaruh pemberian ampas tahu dan gamal terhadap peningkatkan bobot badan harian (PBBH) dianalisis menggunakan uji f. Pada penelitian ini digunakan Rancangan Acak Lengkap (RAL) dengan analisis statistik sidik ragam (ANOVA) dengan menggunakan program SPSS versi 15.0, jika perlakuan berpengaruh nyata terhadap peubah yang diamati maka akan dilanjutkan dengan uji Beda Nyata Terkecil (BNT) pada taraf $1 \%$.

\section{HASIL DAN PEMBAHASAN}

\section{Pertambahan Bobot Badan Harian (PBBH)}

Perubahan yang diamati adalah laju pertambahan bobot badan harian (PBBH). Hasil kegiatan kaji terap yang telah dilaksanakan mendapatkan hasil rata-rata pertambahan bobot badan harian ternak. Pertambahan bobot badan adalah kemampuan ternak untuk mengubah zat-zat nutrisi yang terdapat dalam pakan menjadi daging. Pertambahan bobot badan merupakan salah satu peubah yang dapat digunakan untuk menilai kualitas bahan makanan ternak. Bobot badan merupakan suatu kriteria pengukuran yang penting dan juga merupakan salah satu dasar pengukuran untuk produksi disamping jumlah anak yang dihasilkan dalam menentukan nilai ekonominya domba ditampilkan pada Tabel 1. 
Tabel 1 Hasil Penimbangan Bobot Badan Harian Domba selama 40 hari

\begin{tabular}{ccccc}
\hline Perlakuan & $\begin{array}{c}\text { Bobot } \\
\text { Badan } \\
\text { Awal }\end{array}$ & $\begin{array}{c}\text { Bobot Badan } \\
\text { Akhir }\end{array}$ & $\begin{array}{c}\text { Kenaikan } \\
\text { (Kg) }\end{array}$ & $\begin{array}{c}\text { PBBH } \\
\text { (gram) }\end{array}$ \\
\hline P0 & 26,67 & 28,33 & 2,3 & 57,5 \\
P1 & 26,67 & 32,33 & 5,79 & 144,75 \\
P2 & 21,33 & 28 & 6,86 & 171,5 \\
P3 & 26 & 29,67 & 4,6 & 115 \\
\hline
\end{tabular}

Sumber: Data primer diolah 2021; (P0 = Kontrol, P1 = Hijauan Ampas Tahu, P2 = Hijauan, Ampas Tahu dan Gamal, P3 = Hijauan Gamal).

Tabel 1 menunjukan rata-rata pertambahan bobot badan harian (PBBH) domba tanpa perlakuan (kontrol) yaitu 57,5 gram/ekor/hari, sedangkan rata-rata $\mathrm{PBBH}$ domba yang diberi pakan hijauan dan ampas tahu yaitu 144,75 gram/ekor/hari, rata-rata $\mathrm{PBBH}$ domba yang diberi pakan hijauan, ampas tahu dan gamal yaitu 171,5 gram/ekor/hari dan rata-rata PBBH domba yang diberi pakan hijauan gamal yaitu 115 gram/ekor/hari. PBBH tertinggi diperoleh domba yang diberikan ampas tahu $25 \%$ dan gamal $15 \%$ dengan peningkatan bobot badan mencapai 171,5 gram/ekor/hari, sedangkan $\mathrm{PBBH}$ rendah diperoleh $\mathrm{PO}$ yang diberikan rumput dengan peningkatan bobot badan mencapai 57,5 $\mathrm{kg} / \mathrm{ekor} /$ hari. Hal ini diperkuat dengan hasil penelitian Herman (1993) yang menyatakan bahwa penggunaan ampas tahu pada domba Priangan dan Ekor Gemuk sapihan dengan bobot awal $11 \mathrm{~kg}$, dapat menghasilkan pertambahan bobot hidup masing-masing 129 dan 173 g/hari dengan konsumsi bahan kering masingmasing 512 dan 639 g/hari. Sebagai analisis secara statistik, maka dilakukan uji sidik ragam dengan hasil analisis yang ditampilkan pada Tabel 2 dan hasil uji beda nyata terkecil pada Tabel 3.

Tabel 2 Hasil Analisis Sidik Ragam PPBH Domba

\begin{tabular}{|c|c|c|c|c|c|c|}
\hline & $\begin{array}{l}\text { umber } \\
\text { agaman }\end{array}$ & DB & JK & $\mathrm{KT}$ & F hitung & $\begin{array}{c}\text { F tabel } \\
0,01\end{array}$ \\
\hline & rlakuan & 3 & 20074,266 & 6691,422 & $15,037^{\star *}$ & 7,59 \\
\hline & alat & 8 & 1966,792 & 2245,849 & & \\
\hline & tal & 12 & & & & \\
\hline $\begin{array}{l}\text { Sumbe } \\
{ }^{* *} \text { ber }\end{array}$ & $\begin{array}{l}\text { Data prir } \\
\text { eda sange }\end{array}$ & $\begin{array}{l}\text { diolah } 2 \\
\text { ata pad }\end{array}$ & taraf $1 \%$ & & & \\
\hline Tabel & Uji beda & ta Terke & I pada Taraf & $\%$ dan $1 \%$ & & \\
\hline No & & Perlaku & & $\begin{array}{l}\text { Rata-rata } \\
\text { PBBH (gr) }\end{array}$ & Notasi & BNT $1 \%$ \\
\hline 1 & PO (Kon & & & 58,33 & $a$ & \\
\hline 2 & P1 (Hija & Ampas & ahu) & 144,91 & b & \\
\hline 3 & $\begin{array}{l}\text { P2 (Hija } \\
\text { Gamal) }\end{array}$ & Ampa & Tahu dan & 171,16 & $b$ & 48,58 \\
\hline 4 & P3 (Hija & Gamal) & & 101,67 & C & \\
\hline
\end{tabular}

Sumber: Data primer diolah 2021 
Berdasarkan hasil BNT pada taraf $1 \%$ membuktikan bahwa perlakuan P2 dan P1 tidak berbeda nyata. selain itu P1 dan P2 berbeda sangat nyata terhadap P0 sedangkan untuk perlakuan P3 menunjukkan hasil yang sama dengan P0. Penambahan ampas tahu sebagai sumber protein pada pakan dapat meningkatkan jumlah asam amino didalam digesta, sehingga mengoptimalkan pertambahan bobot badan ternak (Duldjaman, 2004). Sesuai dengan Mathius dan Sinurat (2001) ampas tahu dapat dijadikan sebagai bahan pakan sumber protein karena mengandung protein kasar cukup tinggi berkisar antara 23-29\%. Pemberian daun gamal yang dilayukan menghasilkan pertambahan bobot badan $111 \mathrm{~g} /$ hari pada domba dan $80 \mathrm{~g} / \mathrm{hari}$ pada kambing (Pasembe et al.,1998). Penelitian Moetkono et al. (2011) menunjukkan ransum yang terdiri atas $75 \%$ rumput lapang dan 25\% ampas tahu merupakan ransum terbaik untuk performa domba lokal yang digemukkan selama 4 minggu. Hernaman et al. (2019) juga menunjukkan hasil yang dicapai pada saat uji coba ke ternak domba berbasis rumput lapangan dengan penggunaan limbah pertanian berupa industri pangan daun ubi jalar secara ad libitum dan limbah industri yaitu ampas tahu menunjukkan hasil yang cukup baik dengan rata rata bobot badan sebesar 55,8g/hari.

\section{Pelaksanaan Penyuluhan}

Pelaksanaan Penyuluhan dilakukan sebanyak 4 kali dari 2 desa yaitu Desa Ciakar dan Desa Kondangjajar dimana 2 kali penyuluhan di Kelompok Tani Muda Taruna II yang dilaksanakan di awal dan diakhir kaji terap. Sedangkan 2 kali penyuluhan berikutnya dilaksanakan di Kelompok Ternak Putra Nusa dan Kelompok Tani Muda Taruna II. Adapun langkah langkah yang dilakukan sebelum pelaksanaan penyuluhan diantaranya menentukan masalah, penyiapan materi dan media penyuluhan, pembuatan dan penyebaran undangan penyuluhan untuk sasaran kelompok dan pelaksanaan penyuluhan dan pengisian daftar hadir. Materi Penyuluhan, LPM, sinopsis dan daftar hadir.

\section{Evaluasi Penyuluhan}

Sebagai upaya untuk mengetahui keberhasilan penyuluhan pemberian ampas tahu untuk meningkatkan bobot badan ternak domba dilakukan pre test (tes awal) dan post test (tes akhir). Tes awal ini berguna untuk mengetahui tingkat pengetahuan dan keterampilan peternak sebelum dilakukan penyuluhan. Setelah itu dilaksanakan penyuluhan tentang pemberian ampas tahu yang sudah direncanakan sebelumnya. Kemudian setelah kegiatan penyuluhan dilaksanakan barulah dilakukan post test (tes akhir). Tes akhir ini berguna untuk mengetahui peningkatan pengetahuan dan keterampilan peternak setelah dilakukannya penyuluhan. Setelah itu skor pre test dan skor post test dibandingkan untuk mengukur tingkat perubahan pengetahuan dan keterampilan peternak tentang pemberian ampas tahu. Kemudian diinterpretasikan dan disimpulkan tingkat keberhasilannya. Apakah berhasil atau tidak penyuluhan tersebut.

Evaluasi penyuluhan pertanian merupakan suatu proses sistematis yang bertujuan untuk memperoleh informasi yang relevan dan mengetahui sejauh mana perubahan perilaku petani dan hambatan yang dihadapi, sejauhmana efektivitas rancangan program penyuluhan pertanian dalam merencanakan program kerja petani (Padmowihardjo, 1999). Data rekapitulasi dari hasil evaluasi awal (pre test) tingkat pengetahuan dan keterampilan peternak di Kelompok tani Muda Taruna II sebelum diberikan penyuluhan dapat dilihat pada Tabel 4. Sedangkan data rekapitulasi dari evaluasi akhir (post test) pada tingkat pengetahuan dan keterampilan peternak di Kelompok tani Muda Taruna II yang ditunjukkan pada Tabel 5. 
Tabel 4 Hasil Pre Test Pengetahuan dan Keterampilan Responden

Pre test

\begin{tabular}{clccc} 
No & Aspek yang dinilai & $\begin{array}{c}\text { Jumlah } \\
\text { nilai }\end{array}$ & $\begin{array}{c}\text { Jumlah nilai } \\
\text { max }\end{array}$ & Persentase \\
\hline 1. & $\begin{array}{l}\text { Pengetahuan pemberian dan } \\
\text { penimbangan ampas tahu }\end{array}$ & 122 & 450 & 27,11 \\
\hline $\begin{array}{l}\text { Keterampilan pemberian dan } \\
\text { penimbangan ampas tahu }\end{array}$ & 235 & 540 & 43,51 \\
\hline
\end{tabular}

Sumber: Data primer diolah 2021

Tabel 5 Hasil Post Test Pengetahuan dan Keterampilan Responden

\begin{tabular}{rlccc}
\hline No & \multicolumn{1}{c}{ Aspek yang dinilai } & Jumlah nilai & $\begin{array}{c}\text { Post test } \\
\text { Jumlah nilai } \\
\text { max }\end{array}$ & Persentase \\
\hline 1. & $\begin{array}{l}\text { Pengetahuan pemberian dan } \\
\text { penimbangan ampas tahu }\end{array}$ & 360 & 450 & 80 \\
2. $\begin{array}{l}\text { Keterampilan pemberian dan } \\
\text { penimbangan ampas tahu }\end{array}$ & 512 & 540 & 94 \\
\end{tabular}

Sumber: Data primer diolah 2021

Tabel 4 menunjukkan bahwa jumlah nilai pre test pengetahuan responden pemberian dan penimbangan ampas tahu sebesar 122 dengan persentase $27,11 \%$. Setelah dilakukan penyuluhan, pengetahuan responden mengalami peningkatan dan perubahan yang signifikan. Hal tersebut dapat dilihat dari Tabel 5 peningkatan nilai post test dengan jumlah nilai sebesar 360 dengan persentase $80 \%$ berada pada kriteria Berhasil. Tabel 4 menunjukkan bahwa jumlah nilai pre test keterampilan responden pemberian dan penimbangan ampas tahu sebesar 235 dengan persentase 43,51\%. Keterampilan responden mengalami peningkatan dan perubahan yang signifikan. Peningkatan nilai post test dengan jumlah nilai sebesar 512 dengan persentase $94 \%$ berada pada kriteria Berhasil. kebanyakan peternak termasuk dalam interval ketiga yaitu 20-27 tahun sebanyak 14 orang $(46,7 \%)$. Hasil analisis secara deskriptif tentang keberhasian penyuluhan terutama pada aspek pengetahuan dan keterampilan dapat dilihat dari Tabel 6.

Tabel 6 Keberhasilan Penyuluhan Tentang Aspek Pengetahuan dan Keterampilan

\begin{tabular}{|c|c|c|c|c|c|c|c|}
\hline \multirow{2}{*}{$\begin{array}{c}\text { Aspek } \\
\text { yang } \\
\text { dinilai }\end{array}$} & \multicolumn{2}{|c|}{$\begin{array}{c}\text { Jumlah } \\
\text { Nilai }\end{array}$} & \multirow{2}{*}{$\begin{array}{r}\text { Jumlah } \\
\text { nilai } \\
\text { max }\end{array}$} & \multirow{2}{*}{$\begin{array}{c}\% \\
\text { pre } \\
\text { test }\end{array}$} & \multirow{2}{*}{$\begin{array}{r}\% \\
\text { post } \\
\text { test }\end{array}$} & \multirow{2}{*}{$\begin{array}{l}\text { Keberhasilan } \\
\text { penyuluhan }\end{array}$} & \multirow[b]{2}{*}{ Kriteria } \\
\hline & $\begin{array}{l}\text { Pre } \\
\text { Test }\end{array}$ & $\begin{array}{r}\text { post } \\
\text { test }\end{array}$ & & & & & \\
\hline Pengetahuan & 122 & 360 & 450 & 27,11 & $80 \%$ & 52,88 & Berhasil \\
\hline Keterampilan & 235 & 512 & 540 & 43,51 & $94 \%$ & 51,29 & Berhasil \\
\hline
\end{tabular}

Sumber: Data primer diolah 2021 


\section{Analisis Usaha}

Berdasarkan hasil analisis usaha dari keempat perlakuan tersebut, dinyatakan bahwa P2 (rumput lapang $60 \%$ dari ransum + ampas tahu $25 \%$ dari ransum + gamal $15 \%$ dari ransum per ekor per hari) mendapat pendapatan sebesar Rp 1.025.910 atau dengan pendapatan per ekornya mencapai Rp. 341.970. Soekartawi (2003) mengemukakan bahwa pendapatan dibagi menjadi dua bagian yaitu ; Pendapatan kotor (Penerimaan) usahatani adalah nilai produksi total usahatani dalam jangka waktu tertentu baik yang dijual, dikonsumsi oleh rumah tangga petani, dan disimpan digudang pada akhir tahun. Sedangkan pendapatan bersih usahatani adalah selisih antara pendapatan kotor usahatani dengan biaya produksi. Analisis usaha bertujuan untuk menilai sejauh mana manfaat yang dapat diperoleh dalam menentukan keuntungan usaha dan kelayakan ekonomi, sehingga dapat direkomendasikan atau tidak kepada peternak. Pengertian layak dalam penilaian studi kelayakan adalah kemungkinan dari gagasan usaha/proyek yang akan dilaksanakan memberikan manfaat (benefit), baik dalam arti finansial maupun dalam arti sosial benefit (Ibrahim 2009).

Dilihat dari nilai $\mathrm{R} / \mathrm{C}$ ratio dari keempat perlakuan menguntungkan, namun yang lebih menguntungkan pada P2. Nilai R/C P2 1,23 berarti setiap penambahan biaya $\mathrm{Rp} 1,00$ akan memperoleh keuntungan sebesar $\mathrm{Rp}$ 0,23. Menurut (Soekartawi 2003), usaha tersebut dikatakan menguntungkan jika nilai $R / C$ Ratio lebih besar dari satu (R/C Ratio >1). Sehingga disimpulkan bahwa usaha ternak domba layak untuk diusahakan. R/C digunakan untuk mengetahui tingkat kelayakan usaha. Dilihat dari $\mathrm{R} / \mathrm{C}$ ratio keempat perlakuan menguntungkan, namun yang lebih menguntungkan pada P2 karena dapat memberikan keuntungan sebesar 0,23\% dari biaya yang dikeluarkan. BEP Harga berdasarkan hasil perhitungan, maka P0 sebesar Rp. 61.342, P1 sebesar Rp. 55.434, P2 sebesar Rp. 52.728 dan P3 sebesar 57.596. Artinya usaha berada pada titik impas jika penjualan P2 sebesar Rp. 52.728 tetapi peternak akan untung jika harga jual >Rp. $52.728 / \mathrm{kg}$. BEP Produksi P0 (79,93 kg), Artinya usaha berada pada titik impas jika hasi produksi sebesar 79,93 kg. BEP Produksi P1 (82,91 $\mathrm{kg}$ ), Artinya usaha berada pada titik impas jika hasi produksi sebesar $82,91 \mathrm{~kg}$. BEP Produksi P2 $(68,57 \mathrm{~kg})$, Artinya usaha berada pada titik impas jika hasi produksi sebesar 68,57 kg. BEP Produksi P3 (79,92 $\mathrm{kg}$ ), Artinya usaha berada pada titik impas jika hasi produksi sebesar 79,92 kg.

\section{SIMPULAN DAN SARAN}

\section{Simpulan}

Adanya peningkatan pengetahuan responden dengan persentase 52,28\% berada pada kriteria berhasil dan peningkatan keterampilan responden dengan persentase 51,29 berada pada kriteria berhasil. Penggunaan Rumput $60 \%$ (1,38 kg/ekor/hari) Ampas Tahu 25\% (500 g/ekor/hari) dan Gamal 15\% (300 g/ekor/hari) mampu meningkatkan $\mathrm{PBBH}$ domba sebesar 171,5 g/ekor/hari. Peningkatan PBBH mampu meningkatkan pendapatan domba per ekor mencapai $\mathrm{Rp}$. 341.970 dengan $R / C$ ratio 1,23 . Hal ini berarti usaha tersebut menguntungkan.

\section{Saran}

Peningkatan pengetahuan dan keterampilan peternak di kelompok tani Muda Taruna II perlu ditingkatkan dengan adanya pembinaan dan pendampingan yang lebih baik lagi. Khususnya tentang optimasi pemanfaatan ampas tahu yang memiliki banyak manfaat yang baik bagi hewan peternak. Khususnya sebagai bahan baku pada pembuatan pakan tambahan untuk ternak domba. 


\section{DAFTAR PUSTAKA}

[BPS]. 2019. Badan Pusat Statistika. Diakses melalui laman https://www.bps.go.id/indicator/ 24/473/1/populasi-dombamenurut-provinsi.html

Duldjaman M, 2004. Penggunaan ampas tahu untuk meningkatkan gizi pakan domba lokal. Media Peternakan. Bogor. Fakultas Peternakan Institut Pertanian Bogor.

Herman R. 1993. Perbandingan pertumbuhan, komposisi tubuh dan karkas antara domba priangan dan ekor gemuk. Program Pascasarjana, Institut Pertanian Bogor, Bogor.

Hernaman I, Budiman A, Wiyatna AF, dan Arifin J. 2019. Aplikasi Penggunaan Daun Ubi Jalar Dan Ampas Tahu Sebagai Pakan Tambahan Untuk Meningkatkan Performa Domba Lokal Di Desa Gudang Kecamatan Tanjungsari. Media Kontak Tani Ternak. 1 (1): 1-4.

Ibrahim. 2009. Rencana dan estimate Real of Cost. Jakarta. penerbit Bumi Aksara.

Mathius IW. dan Sinurat AP. 2001. Pemanfaatan bahan pakan inkonvensional untuk ternak. Wartazoa, 11(2), 20-31.

Moetkono OAF, Kardaya D, dan Sudrajat D. 2011. Performa Domba Lokal yang Diberi Ransum Rumput Lapang dan Ampas Tahu yang Dipelihara Secara Tradisional. Jurnal Pertanian. 2 (2): 88-94.

Padmowihardjo S. 1999. Psikologi Belajar Mengajar. Jakarta, Universitas Terbuka.

Pasembe D, M Sariubang, dan R Haryani. 1998. Substitusi daun gamal dalam pakan untuk meningkatkan produktivitas ternak ruminansia. Seminar pakan domba lokal. Media Nasional Peternakan dan Veteriner. hlm. 520522.
Provinsi Jawa Barat. 2021. https://opendata.jabarprov.go.i $\mathrm{d} /$ id/dataset/populasi-dombaberdasarkan kabupatenkota-dijawa-barat diakses pada tanggal 1 Agustus 2021.

Prabowo,dkk. 1993. Pemanfaatan amapas tahu sebagai makanan tambahan dalam usaha penggemukan domba potong. Proceeding Seminar 1983. Lembaga Kimia Nasional.LIPI. Bandung.

Soekartawi, Soehardjo A, Dillon JL, and Hhardaker JB. 1994. Jakarta. IImu Usahatani dan Penelitian untuk Pengembangan Petani Kecil. UI Press.

Widjatmoko. 1996. Penggunaan Ampas Tahu dalam Ransum Unggas. Poultry Indonesia, Jakarta. 